\begin{tabular}{|c|l|}
\hline Title & Risk assessment of ozone impact on the carbon absorption of Japanese representative conifers \\
\hline Author(s) & Watanabe, Makoto; Matsuo, Naoki; Y amaguchi, Masahiro; Matsumura, Hidey uki; Kohno, Y oshihisa; Izuta, Takeshi \\
\hline Citation & $\begin{array}{l}\text { European Journal of Forest Research, 129(3), 421-430 } \\
\text { https://doi.org/10.1007/\$10342-009-0316-0 }\end{array}$ \\
\hline Issue Date & 2009 \\
\hline Doc URL & http://hdl.handle.net/2115/47539 \\
\hline Type & article (author version) \\
\hline File Information & wm.pdf \\
\hline
\end{tabular}

Instructions for use 
Title

\section{Risk assessment of ozone impact on the carbon absorption of Japanese representative conifers}

\section{Names of authors}

Makoto Watanabe ${ }^{1}$, Naoki Matsuo ${ }^{2}$, Masahiro Yamaguchi ${ }^{3}$, Hideyuki Matsumura ${ }^{4}$, Yoshihisa Kohno ${ }^{4}$ and Takeshi Izuta ${ }^{5 *}$

\section{Affiliations and addresses}

1 JSPS Research Fellow, Faculty of Agriculture, Hokkaido University, Sapporo 060-8589, Japan

${ }^{2}$ Graduate School of Agricultural Science, Tokyo University of Agriculture and Technology, Fuchu, Tokyo 183-8509, Japan.

${ }^{3}$ United Graduate School of Agricultural Science, Tokyo University of Agriculture and Technology, Fuchu, Tokyo 183-8509, Japan.

${ }^{4}$ Environmental Science Research Laboratory, Central Research Institute of Electric Power Industry, Abiko, Chiba 270-1194, Japan.

${ }^{5}$ Institute of Symbiotic Science and Technology, Tokyo University of Agriculture and Technology, Fuchu, Tokyo 183-8509, Japan.

\section{Corresponding author}

Takeshi Izuta,

Tel. \& Fax.: +81-42-367-5728, E-mail: izuta@cc.tuat.ac.jp

Fuchu, Tokyo 183-8509, Japan. 


\section{Abstract}

A risk assessment of ozone $\left(\mathrm{O}_{3}\right)$ impact on the annual carbon absorption $(A C A)$ of Japanese representative conifers was conducted based on the results of an experimental study, monitoring data of oxidant concentrations and vegetation surveys. The areas with high $\mathrm{O}_{3}$-induced reduction in $A C A$ did not necessarily correspond to the areas with relatively high $\mathrm{O}_{3}$-exposure. Widespread distribution of $\mathrm{O}_{3}$-sensitive tree species such as $P$. densiflora and L. kaempferi, and high ACA were important factors that induced a high risk of $\mathrm{O}_{3}$ impact on the $A C A$. Therefore, we concluded that not only the accumulated $\mathrm{O}_{3}$-exposure but also the variety of tree habitat, the tree sensitivity to $\mathrm{O}_{3}$ and the $A C A$ among the tree species must be taken into account to assess the risk of $\mathrm{O}_{3}$ impact on the $A C A$ of Japanese conifers. The $\mathrm{O}_{3}$-induced reduction in the total $A C A$ of the three tree species in Japan was estimated to be $0.8 \%$.

\section{Keywords}

ozone, annual carbon absorption, Japanese conifers, risk assessment

\section{Introduction}

Ozone $\left(\mathrm{O}_{3}\right)$ in the troposphere is recognized as a widespread phytotoxic gaseous air pollutant and its concentrations have been increasing in the Northern Hemisphere (Akimoto 2003; ADORC 2006). The annual average concentration of photochemical oxidant, whose main component is $\mathrm{O}_{3}$, during the daytime throughout Japan increased from 1985 to 1999 with the rate of increase being $0.33 \mathrm{nmol} \mathrm{mol}^{-1}$ year $^{-1}$ and was about $31 \mathrm{nmol} \mathrm{mol}^{-1}$ as an average from 1999 to 2002 (Ohara and Sakata 2003; ADORC 2006). Furthermore, relatively high concentrations of $\mathrm{O}_{3}$ 
above $100 \mathrm{nmol} \mathrm{mol}^{-1}$ have been frequently detected not only in the suburbs of big cities such as Tokyo and Osaka, but also in several mountainous areas (Wakamatsu et al. 1998; Yoshikado 2004; Network Center for EANET 2007; Takeda et al. 2007).

Assimilation of $\mathrm{CO}_{2}$ by forest tree species reduces atmospheric $\mathrm{CO}_{2}$ concentration and contributes to the mitigation of global warming. However, many experimental studies have indicated that the ambient levels of $\mathrm{O}_{3}$ reduce the dry matter production and net photosynthesis of forest tree species (Matsumura et al. 2001; Matyssek and Sandermann 2003; Oksanen 2003; Karnosky et al. 2005; Watanabe et al. 2006, 2007; Karlsson et al. 2007). Sitch et al. (2007) suggested that the $\mathrm{O}_{3}$-induced reduction in the capacity of $\mathrm{CO}_{2}$ absorption of terrestrial vegetation could contribute more to global warming than the radiative forcing of $\mathrm{O}_{3}$ itself.

The extent of the negative impact of $\mathrm{O}_{3}$ is considerably different among tree species (Kohno et al. 2005; Watanabe et al. 2006; Karlsson et al. 2007), which is one of the most important factors affecting the risk of $\mathrm{O}_{3}$ impact on the carbon absorption capacity of forest tree species. The risk of $\mathrm{O}_{3}$ impact in the habitats of $\mathrm{O}_{3}$-sensitive tree species is greater than that in the habitats of $\mathrm{O}_{3}$-tolerant tree species, even when the $\mathrm{O}_{3}$ levels are the same. Furthermore, the difference in the degree of carbon absorption among the areas is an important factor. A reduction in the atmospheric concentration of $\mathrm{O}_{3}$ in areas with a high degree of carbon absorption would be effective in mitigating global warming.

Cryptomeria japonica, Pinus densiflora and Larix kaempferi are important tree species for forestation in Japan. $C$. japonica and $P$. densiflora are evergreen coniferous species and are widely distributed in the temperate region of Japan (Hirai 1980a, 1980b). L. kaempferi is a deciduous coniferous species and is distributed in the northern part and in the highland of the central part of Japan (Hirai 1980a). 
Although the three tree species were planted for the production of timber during the period between the 1950s and the 1970s, presently, the planted forests play an important role in carbon absorption under the Kyoto Protocol (Forestry and Forest Products Research Institute 2004). Watanabe et al. (2006) reported that the extent of $\mathrm{O}_{3}$-induced reduction in the whole-plant growth of L. kaempferi and P. densiflora seedlings was greater than that of $C$. japonica seedlings. There are several variations in the habitats, the sensitivity of the trees to $\mathrm{O}_{3}$ and the amount of carbon absorption among $C$. japonica, P. densiflora and L. kaempferi grown in Japan. Therefore, we hypothesized that areas with a high risk of $\mathrm{O}_{3}$ impact on the carbon absorption of the three tree species would not necessarily correspond to areas with a high $\mathrm{O}_{3}$-exposure. To test this hypothesis, we assessed the risk of $\mathrm{O}_{3}$ impact on the annual carbon absorption $(A C A)$ of $C$. japonica, P. densiflora and L. kaempferi in Japan based on the results of an experimental study and statistical data such as atmospheric $\mathrm{O}_{3}$ concentrations and vegetation surveys.

\section{Materials and methods}

\subsection{Experimental evaluation of the impact of ozone on the carbon absorption}

\subsubsection{Experimental design}

In the present study, the $\mathrm{O}_{3}$ exposure-response relationships of annual carbon absorption $(A C A)$ of $C$. japonica, P. densiflora and L. kaempferi were evaluated based on the experimental study reported by Watanabe et al. (2006). In this experiment, the seedlings of $C$. japonica, $P$. densiflora and L. kaempferi were grown in 12 experimental treatments, which were comprised of 4 gas treatments [charcoal-filtered air $(\mathrm{CF})$ and 3 levels of $\mathrm{O}_{3}$ at $1.0\left(\mathrm{O}_{3} \times 1.0\right), 1.5\left(\mathrm{O}_{3} \times 1.5\right)$ and 2.0 
times the ambient concentration $\left.\left(\mathrm{O}_{3} \times 2.0\right)\right]$ in combination with 3 soil nitrogen $(\mathrm{N})$ treatments with $\mathrm{NH}_{4} \mathrm{NO}_{3}\left(0,20\right.$ and $50 \mathrm{~kg} \mathrm{~N} \mathrm{ha}^{-1}$ year $\left.^{-1}\right)$ in open-top chambers during the 2 growing seasons. The average 24-h concentration of $\mathrm{O}_{3}$ in the $\mathrm{CF}, \mathrm{O}_{3} \times 1.0$, $\mathrm{O}_{3} \times 1.5$ and $\mathrm{O}_{3} \times 2.0$ treatments from April to September of the 2 growing seasons were $11.7,42.6,63.3$ and $83.7 \mathrm{nmol} \mathrm{mol}^{-1}$, respectively.

The average annual wet deposition rate of inorganic $\mathrm{N}$ (sum of $\mathrm{NO}_{3}{ }^{-}$and $\mathrm{NH}_{4}^{+}$) throughout Japan from 1998 to 2002 was $7.2 \mathrm{~kg} \mathrm{~N}^{-1}$ year ${ }^{-1}$ (Ministry of Environment 2004). Because the dry deposition rate of $\mathrm{N}$ is considered to be similar to the wet deposition rate of $\mathrm{N}$ (Matsuda et al., 2001), the total annual $\mathrm{N}$ deposition (sum of wet deposition and dry deposition) in Japan can be estimated to be around $15 \mathrm{~kg} \mathrm{~N}^{-1}$ year $^{-1}$. This deposition rate was the closest to the treatment with the $\mathrm{N}$ supply at $20 \mathrm{~kg} \mathrm{~N} \mathrm{ha}^{-1}$ year $^{-1}$ in Watanabe et al. (2006). Therefore, we evaluated the effects of $\mathrm{O}_{3}$ on the ACA of C. japonica, P. densiflora and L. kaempferi based on the results obtained from the seedlings grown in the soil supplied with $\mathrm{N}$ at $20 \mathrm{~kg} \mathrm{~N}^{-1}$ year $^{-1}$.

\subsubsection{Calculation of annual carbon absorption of the seedlings}

The experiment was conducted during the 2 growing seasons from April 2004 to November 2005. At the end of the first and second growing seasons, the seedlings were harvested to determine the dry mass and carbon concentration in the plant organs. The harvested samples were separated into needles, stems and roots. The plant organs were dried at $80{ }^{\circ} \mathrm{C}$ for 1 week and weighed. Dried samples were ground to a fine powder with a sample mill. The concentration of carbon in each plant organ was determined with a $\mathrm{C} / \mathrm{N}$ analyzer (MT-700, Yanako, Japan). The whole-plant carbon content of the seedlings was calculated as a sum of the product of 
the dry mass and the carbon concentration in each plant organ. The $A C A$ of the seedlings was calculated as the difference between the whole-plant carbon content of the seedlings at the end of the first growing season and that at the end of the second growing season.

\subsubsection{Analyses of ozone exposure-response relationships}

The AOTX (accumulated exposure over a threshold of $\mathrm{X} \mathrm{nmol} \mathrm{mol}{ }^{-1}, \mathrm{X}=0$, 20, 40, 60, 80 and 100) of $\mathrm{O}_{3}$ from April to September of the second growing season in 2005 were calculated based upon the monitoring data of atmospheric $\mathrm{O}_{3}$ concentration in the OTCs. The AOTX was accumulated for $12 \mathrm{~h}$ (0600-1800 hours). The analyses of the $\mathrm{O}_{3}$ exposure-response relationships for the $A C A$ were performed by the methods described below. A regression line was obtained from the relationship between AOTX and the $A C A$. The theoretical $A C A$ at zero AOTX was determined to be the $y$-axis intercept of the regression line. The theoretical ACA at zero AOTX was used as a reference $(100 \%)$ to calculate the relative $A C A$ for each gas treatment. The slope and coefficient of determination values $\left(R^{2}\right)$ were calculated from the regression line between AOTX and the relative $A C A$.

Table 1 indicates the slope and coefficient of determination $\left(R^{2}\right)$ values of the linear regression between the $\mathrm{O}_{3}$-exposure indices and relative reduction in the ACA of C. japonica, P. densiflora and L. kaempferi seedlings. The degree of $\mathrm{O}_{3}$-induced reduction in the $A C A$ of $P$. densiflora and $L$. kaempferi was greater than that in $C$. japonica. In AOT60 and AOT80, significant regression lines were found in both of $C$. japonica and $P$. densiflora seedlings. Although no significant regression line was found for L. kaempferi seedlings, highest $R^{2}$ was detected in AOT60 $(P=$ 0.067). Therefore, we employed the AOT60 as common $\mathrm{O}_{3}$-exposure index for the 
risk assessment of $\mathrm{O}_{3}$ impact on the carbon absorption of the three tree species.

\subsection{Estimation of AOT60 in habitat of Japan}

The concentrations of photochemical oxidants are officially monitored at approximately 1200 monitoring stations in Japan. Originally, photochemical oxidants have been measured by absorption spectrophotometry using a neutral potassium iodide solution (AS-NPI). The atmospheric concentration of $\mathrm{O}_{3}$ can be tabulated as that of photochemical oxidants under the Air Pollution Control Law Enforcement Regulations in Japan from 1996, because of following reasons: a) the concentration of peroxi-acetyl nitrate (PAN), main component of photochemical oxidant without $\mathrm{O}_{3}$, was very low and b) the sensitivity of AS-NPI to PAN concentration was low (Ministry of Environment 1996). In fact, the 1-year field measurement indicated that the little difference between the concentrations of $\mathrm{O}_{3}$ measured by $\mathrm{UV}$ absorption photometry and chemiluminescence method and that of photochemical oxidant measured by AS-NPI (Ministry of Environment 1996). In the present study, therefore, the concentration of photochemical oxidants was regarded as that of $\mathrm{O}_{3}$.

The number of hours with a concentration of $\mathrm{O}_{3}$ above $0.06 \mu \mathrm{mol} \mathrm{mol}{ }^{-1}$ $\left(N_{60}\right)$ and that above $0.12 \mu \mathrm{mol} \mathrm{mol}^{-1}\left(N_{120}\right)$ at all the monitoring stations in Japan are officially tabulated and can be obtained from the web site of National Institute for Environmental Studies (http://www.nies.go.jp/igreen/index.html). However, hourly data of $\mathrm{O}_{3}$ concentration were available in limited number (approximately $40 \%$ ) of prefectures. Ishii et al. (2007) developed the method for the estimation of AOT40 from the $N_{60}$ and $N_{120}$. Based on the available hourly data of $\mathrm{O}_{3}$ concentration, they found the high correlation between the sum of the $N_{60}$ and $N_{120}$, and observed the AOT40 for $12 \mathrm{~h}$ (0600-1800 hours) from April to September. Therefore, we 
estimated the AOT60 of $\mathrm{O}_{3}$ at all the monitoring stations in Japan by using the modified method of Ishii et al. (2007).

Original formula of Ishii et al. (2007) expressed the AOT40 as follows:

$\mathrm{AOT} 40=\mathrm{a} \times\left(N_{60}+N_{120}\right)$.

Because $N_{120}$ contributes more to AOT60 than $N_{60}$, we added the weighting factor for $N_{120}$ :

$\mathrm{AOT} 60=\mathrm{a} \times\left(N_{60}+\mathrm{b} \times N_{120}\right)$.

The coefficients that indicated best correlation between estimated AOT60 and observed AOT60 were calculated by solver function of spreadsheet software (Excel 2003, Microsoft, Redmond, WA, USA). We used the data of $N_{60}, N_{120}$ and available $\mathrm{O}_{3}$ concentration from 2000 to 2004 for the estimation of AOT60 $\left(\mu \mathrm{mol} \mathrm{mol}{ }^{-1} \mathrm{~h}\right)$ and obtained the coefficients: $\mathrm{a}=12.86$ and $\mathrm{b}=11.05$.

The map of spatial distribution of AOT60 in Japan was created using the Geostatistical Analyst Extension of the ArcGIS 9.0 software (ESRI inc. USA). The kriging interpolation was applied for the estimation of AOT60 among the monitoring stations. The cell size in the kriging interpolation was set as $0.05^{\circ}$. The Gaussian model was used as a semivariogram model in the kriging interpolation because the kriging variance was lower than that of the other semivariogram models (Spherical, Circular, Exponential and Linear).

The habitats of $C$. japonica, P. densiflora and L. kaempferi in Japan were determined based on the vegetation raster data $\left(45^{\prime \prime} \times 30 "\right.$ per mesh) of the National 
Survey on the Natural Environment, carried out by the Ministry of the Environment. These raster data were obtained from the web site of the Japan Integrated Biodiversity Information System (http://www.biodic.go.jp/J-IBIS.html). The geographical meshes that contain the vegetation code of $C$. japonica, $P$. densiflora

and L. kaempferi were extracted as their habitat, as shown in Fig. 1. The AOT60 of $\mathrm{O}_{3}$ in each habitat of the three tree species was extracted from the above-mentioned AOT60 map and was averaged in each prefecture.

\subsection{Estimation of ozone-induced reduction in the annual carbon absorption}

The calculation method for the ACA of $C$. japonica, $P$. densiflora and $L$. kaempferi was according to Forestry and Forest Products Research Institute (2004) and is described below. The calculation was conducted in each prefecture and for each tree species. We obtained the data of the forest resource assessment from the web site of the Forestry Agency of Japan (http://www.rinya.maff.go.jp/toukei/genkyou/index.htm). The data contain the basal area (ha) and stand volume $\left(\mathrm{m}^{3}\right)$ of $C$. japonica, P. densiflora and L. kaempferi in each forest age class from planting seedlings. The forest age class was delimited in 5 years, i.e. Class $1=1-5$ years, Class $2=6-10$ years etc. Stem volume per basal area $\left(\mathrm{m}^{3} \mathrm{ha}^{-1}\right)$ was calculated and converted to the carbon content of each organ (leaf, stem + branches, and root) per basal area $(\mathrm{kg}$ carbon $\mathrm{ha}^{-1}$ ) according to the following formula:

Carbon content $=$ Stem volume $\times$ Basic density $\times$ Conversion coefficient $\times$ Carbon concentration 
Basic densities (the ratio of stem dry mass to stem volume) were according to the data from the Forestry Experiment Station (1982), i.e. $316 \mathrm{~kg} \mathrm{~m}^{-3}$ for C. japonica, $405 \mathrm{~kg} \mathrm{~m}^{-3}$ for $P$. densiflora and $444 \mathrm{~kg} \mathrm{~m}^{-3}$ for $L$. kaempferi. The conversion coefficient was the ratio of the dry mass of the each organ to that of stem; values were obtained from the Forestry and Forest Products Research Institute (2004). The carbon concentration of each tree organ obtained from the experimental study described above was used for this calculation of carbon content. Because the exposure to $\mathrm{O}_{3}$ little affected the carbon concentration of the organs in the three tree species as shown in Table 2, the carbon concentrations in each gas treatment were averaged and used for the calculation.

The carbon content of the whole-tree per basal area was calculated as the sum of the carbon contents of leaf, stem + branch and root. The Gompertz curve was fitted to the relationship between forest age class and carbon content of the whole-tree per basal area (Fig. 2, Forestry and Forest Products Research Institute, 2004). The fifth part of the difference between the carbon content of the whole-tree per basal area of an age class and that of the next age class was calculated based on the regression curve, and regarded as the $A C A$ per basal area in each forest age class. The $\mathrm{O}_{3}$-induced reduction in the $A C A$ per prefecture $\left(C_{\text {red, }} \mathrm{Gg}\right.$ carbon year $\left.{ }^{-1}\right)$ of each forest age class was calculated by the following formula:

$C_{\text {red }}=C_{\text {abs }} \times R \times$ AOT $60 \times$ Basal area,

where $C_{\text {abs }}$ is the $A C A$ per basal area $\left(\mathrm{Gg}\right.$ carbon $\mathrm{ha}^{-1}$ year $\left.^{-1}\right)$ and $R$ is the rate of reduction in the $A C A$ per unit AOT60, which is the absolute value of the slope of the regression line between AOT60 and ACA, obtained from the experimental study 
(Table 1). This $C_{\text {red }}$ indicated the reduction in the $A C A$ at an AOT60 compared to that at zero AOT60. Finally, the $C_{\text {red }}$ of all forest age classes was summed up.

\section{Results}

\subsection{Estimation of AOT60 in Japan}

The relationship between the estimated AOT60 and observed AOT60 is shown in Fig. 3. High correlation along the 1:1 line was observed although a little over estimation and under estimation were found in relatively low and high AOT60, respectively. Figure 4 illustrates the map of the estimated AOT60 of $\mathrm{O}_{3}$ in Japan. The highest AOT60 was estimated in the western part of the Kanto region. Relatively high AOT60 values were estimated not only in the metropolitan areas of Tokyo and Osaka but also in the countryside such as the northern part of the Chubu region and the northern part of the Chugoku region.

\section{1 $\mathrm{O}_{3}$-induced reduction in annual carbon absorption}

The estimated $C_{\text {red }}$ in each prefecture is shown in Table 3. The prefectures that indicated relatively high $C_{\text {red }}$ were different among the three tree species. Relatively high $C_{\text {red }}$ was estimated in Gunma, Akita and Miyazaki Prefectures for C. japonica; Shimane, Iwate and Gunma Prefectures for P. densiflora; and Nagano, Gunma and Yamanashi Prefectures for L. kaempferi. The average and maximum rates of the $C_{\text {red }}$ in Japan were estimated to be $0.7 \%$ and $2.1 \%$ for $C$. japonica, $1.2 \%$ and $3.6 \%$ for P. densiflora and $1.4 \%$ and $3.4 \%$ for L. kaempferi, respectively. The total $C_{\text {red }}$ of the three tree species in all prefectures was estimated to be $0.8 \%$.

Figure 5 illustrates the map of the total $C_{\text {red }}$ of the three tree species in Japan. The total $C_{\text {red }}$ of the three tree species in Nagano, Gunma, Akita and Iwate 
Prefectures were relatively high as compared with that of the other prefectures. The areas with relatively high AOT60 of $\mathrm{O}_{3}$ did not necessarily correspond to areas with high $C_{\text {red. }}$ Although the AOT60 in Nagano, Akita and Iwate Prefectures were not as high as that in the other prefectures, the extents of the estimated $C_{\text {red }}$ in these prefectures were relatively high (Figs. 4 and 5). In Nagano and Iwate Prefectures, this phenomenon was mainly attributed to the widespread distribution of $\mathrm{O}_{3}$ sensitive species L. kaempferi and P. densiflora (Fig. 1 and Table 1). In Akita Prefecture, on the other hand, $C$. japonica was the primary tree species. The rate of the $C_{\text {red }}$ of C. japonica in this prefecture was relatively low because of the relatively low AOT60 and good $\mathrm{O}_{3}$ tolerance of $C$. japonica (Fig. 4 and Table 1). However, the $A C A$ of $C$. japonica in Akita Prefecture was highest among all the prefectures, as shown in Fig. 6. Therefore, we conclude that the high $C_{\text {red }}$ in this prefecture was mainly due to the accumulation of small effect on individual trees of $C$. japonica. This accumulation effect also contributed to the high $C_{\text {red }}$ of $P$. densiflora in Iwate and that of L. kaempferi in Nagano Prefectures (Fig. 6 and Table 3).

\section{Discussion}

In Europe, the risk assessment of $\mathrm{O}_{3}$ impact on forest trees had been conducted based on the concept of critical level (Mills 2004). The critical level of $\mathrm{O}_{3}$ for forest trees was evaluated from the relationship between the growth of seedlings of $\mathrm{O}_{3}$-sensitive tree species and accumulated exposure (e.g. AOTX) or accumulated stomatal flux (e.g. $\mathrm{AF}_{\mathrm{st}} \mathrm{Y}$ ) of $\mathrm{O}_{3}$ by the analysis of $99 \%$ confidence limits of the regression line (Karlsson et al. 2004; Mills 2004; Karlsson et al. 2007). The areas exceeding the critical level of $\mathrm{O}_{3}$ were detected as high-risk areas (Simpson et al. 2007). This risk assessment is easy to understand and useful, for example, in the 
formulation of policy aimed at a reduction in the precursors of $\mathrm{O}_{3}$. In the present study, on the other hand, we focused not only on accumulated $\mathrm{O}_{3}$-exposure but also on the variety of tree habitat, the sensitivity of tree species to $\mathrm{O}_{3}$ and the $A C A$ among the three tree species for evaluating the risk of $\mathrm{O}_{3}$ impact on the $A C A$. As a result, we estimated a relatively high risk of $\mathrm{O}_{3}$ impact on the $A C A$ in the areas where the AOT60 of $\mathrm{O}_{3}$ was relatively low and where the $\mathrm{O}_{3}$-tolerant species, $C$. japonica, was primary species (Figs. 1, 4 and 5). Our results indicate that the variety of tree habitat, tree sensitivity to $\mathrm{O}_{3}$ and the $A C A$ among the tree species must be taken into account to assess the risk of $\mathrm{O}_{3}$ impact on the carbon absorption of forest tree species.

Recently, the risk of $\mathrm{O}_{3}$ has been mainly assessed based on the index of the accumulated stomatal flux of $\mathrm{O}_{3}$, while the exposure index was retained as the recommended method for calculating critical levels for forest tree species (Emberson et al. 2000; Mills 2004; Matyssek et al 2007; Simpson et al. 2007). This change from the assessment by exposure basis to that by flux basis is reasonable because the main impact was induced by the $\mathrm{O}_{3}$ that enters the plants' leaves through the stomata (Reich 1987). The stomatal uptake of $\mathrm{O}_{3}$ reduces under dry conditions such as the summer of the Mediterranean region, whereas relatively high $\mathrm{O}_{3}$ concentration is observed in this region (Ferretti et al. 2007). On the other hand, the $\mathrm{O}_{3}$ uptake of the trees grown in northern latitudes of Europe becomes high due to high air humidity and long days even the $\mathrm{O}_{3}$ concentration is relatively low (Simpson et al. 2007). Unfortunately, we could not use the data of hourly $\mathrm{O}_{3}$ concentrations from many monitoring stations in Japan. Currently, it is therefore difficult to assess the risk of $\mathrm{O}_{3}$ impact in Japan based on the accumulated stomatal flux of $\mathrm{O}_{3}$. However, it is to be noted that since Japan is a country where precipitation ranging from 1100 to 2300 $\mathrm{mm}$ and air humidity is generally high, drought-induced stomatal closure would not 
be as frequent as that in European countries (National Astronomical Observatory 2007; Ministry of Land, Infrastructure, Transport and Tourism 2008).

To evaluate the changes in the risk of $\mathrm{O}_{3}$ impact on the $A C A$ of $C$. japonica, P. densiflora and L. kaempferi with the increasing concentrations of $\mathrm{O}_{3}$ in Japan (Ohara and Sakata 2003; ADORC 2006), we compared the estimated $C_{\text {red }}$ based on the AOT60 of $\mathrm{O}_{3}$ from 2000 to 2004 and that from 1990 to 1994 . The ratio of the total $C_{r e d}$ of the three tree species in all the prefectures from 2000 to $2004(91.0 \mathrm{Gg}$ carbon year $\left.^{-1}\right)$ to that from 1990 to $1994\left(69.2 \mathrm{Gg}_{\text {carbon year }}{ }^{-1}\right)$ was calculated to be $136 \%$. One of the main reasons for this rapid increase in the risk of $\mathrm{O}_{3}$ impact on the $C_{r e d}$ in Japan is considered to be transboundary air pollution from other East Asian countries (Ohara and Sakata 2003; Tanimoto et al. 2005; ADORC 2006; Yamaji et al. 2006). Many researchers have predicted that the increase in $\mathrm{O}_{3}$ concentration in Japan will continue with the increasing emissions of precursors of $\mathrm{O}_{3}$ such as $\mathrm{NO}_{\mathrm{x}}$ and volatile organic compounds from other East Asian countries in the near future (Prather et al. 2001; Stevenson et al. 2006; Ohara et al. 2007). Therefore, the development of control policies for lowered emissions of precursors of $\mathrm{O}_{3}$ in East Asian countries is crucially important for reducing the risk of $\mathrm{O}_{3}$ impact on Japanese forest tree species. This reduction leads to the mitigation of global warming not only by reduction in radiative forcing of $\mathrm{O}_{3}$ but also by the stimulation of $\mathrm{CO}_{2}$ absorption by forest trees (Sitch et al. 2007).

Many reports indicate $\mathrm{O}_{3}$-induced change of structural and metabolic carbon allocations of tree species. It has been well documented that the $\mathrm{O}_{3}$ increased the shoot/root ratio (Matyssek et al. 1992; Landolt et al. 2000; Witting et al. 2009). In the leaves exposed to $\mathrm{O}_{3}$, more carbon would be distributed to the functions of detoxification for $\mathrm{O}_{3}$ and its derivations, and repair for injured organs (Fuhrer and 
Booker 2003; Castagna and Ranieri 2009). On the other hand, several researchers reported that $\mathrm{O}_{3}$-induced increase of dark respiration, which leads to carbon loss back to the atmosphere (Wallin et al. 1990; Maurer et al. 1997). These structural and metabolic changes of carbon allocation induced by $\mathrm{O}_{3}$ will affect the net carbon uptake of the trees, especially as long-term accumulated effects. In the future, therefore, we must develop the estimation model with structural and metabolic processes for the risk assessment of $\mathrm{O}_{3}$ impact on the $A C A$ of Japanese coniferous forest tree species.

In conclusion, the results obtained from the present study support our hypothesis that the area with a high risk of $\mathrm{O}_{3}$ impact on the $A C A$ of the three tree species does not necessarily correspond to the area with high $\mathrm{O}_{3}$-exposure. Widespread distribution of $\mathrm{O}_{3}$-sensitive tree species such as $P$. densiflora and L. kaempferi and high $A C A$ were important factors that induced a high risk of $\mathrm{O}_{3}$ impact on the $A C A$. Therefore, we must take into account not only the accumulated $\mathrm{O}_{3}$-exposure but also the variety of tree habitat, tree sensitivity to $\mathrm{O}_{3}$ and the $A C A$ among the tree species to assess the risk of $\mathrm{O}_{3}$ impact on the carbon absorption of Japanese conifers.

\section{Acknowledgments}

This study was partly supported by the Ministry of the Environment, Japan, through the program of Global Environmental Research Fund (C-03-07, 2003-2005) and by the Japan Society for the Promotion of Science Research Fellowships for Young Scientists. The authors are greatly indebted to M. Iwasaki, J. Naba, C. Tabe, R. Yamashita, Y. Shinozaki and M. Tanaka (Tokyo University of Agriculture and Technology), and the staff of CERES Inc. for their technical support and discussion. 
We have used the data file of photochemical oxidants from the 'Numerical database for environment' of the National Institute for Environmental Studies, Japan.

\section{Reference}

ADORC (Acid deposition and oxidant research center) (ed) (2006) Tropospheric ozone a growing threat. ADORC, Niigata, p 26

Akimoto H (2003) Global air quality and pollution. Science 302:1716-1719

Castagna A, Ranieri A (2009) Detoxification and repair process of ozone injury: from $\mathrm{O}_{3}$ uptake to gene expression adjustment. Environ Pollut 157:1461-1469

Emberson LD, Ashmore MR, Cambridge HM, Simpson D, Tuovinen J-P (2000) Modelling stomatal ozone flux across Europe. Environ Pollut 109:403-413

Ferretti M, Fagnano M, Amoriello T, Badiani M, Ballarin-Denti A, Buffoni A, Bussotti F, Castagna A, Cieslik S, Costantini A, De Marco A, Gerosa G, Lorenzini G, Manes F, Merola G, Nali C, Paoletti E, Petriccione B, Racalbuto S, Rana G, Ranieri A, Tagliaferri A, Vialetto G, Vitale M (2007) Measuring, modelling and testing ozone exposure, flux and effects on vegetation in southern European conditions--what does not work? A review from Italy. Environ pollut 146:648-58

Forestry and Forest Products Research Institute (ed) (2004) Upgrading of evaluation for the budget of Carbon dioxide in forests and oceans. Forestry and Forest Products Research Institute, Tsukuba, p 155. In Japanese

Forestry Experiment Station (ed) (1982) Handbook of the Wood Industry. Maruzen, Tokyo, p 1099. In Japanese

Fuhrer J, Booker F (2003) Ecological issues related to ozone: agricultural issues. Environ Int 29:141-154 
Hirai S (ed) (1980a) Cyclopedia of wood Vol. 1, No. 6. Kanae Shobo, Tokyo. In Japanese

Hirai S (ed) (1980b) Cyclopedia of wood Vol. 1, No. 7. Kanae Shobo, Tokyo. In Japanese

Ishii T, Matsumura H, Hayami H, Kohno Y (2007) Relationship between oxidant-based AOT40 and forest environmental conditions of damaged Japanese cedars in the Kanto plains. J Glob Environ Eng 12:51-62

Karlsson PE, Uddling J, Braun S, Broadmeadow M, Elvira S, Gimeno BS, Le Thiec D, Oksanen E, Vandermeiren K, Wilkinson M, Emberson L (2004) New critical levels for ozone effects on young trees based on AOT40 and simulated cumulative leaf uptake of ozone. Atmos Environ 38:2283-2294

Karlsson PE, Braun S, Broadmeadow M, Elvira S, Emberson L, Gimeno BS, Le Thiec D, Novak K, Oksanen E, Schaub M, Uddling J, Wilkinson M (2007) Risk assessments for forest trees: The performance of the ozone flux versus the AOT concepts. Environ Pollut 146:608-616

Karnosky DF, Pregitzer KS, Zak DR, Kubiske ME, Hendrey GR, Weinstein D, Nosal M, Percy KE (2005) Scaling ozone responses of forest trees to the ecosystem level in a changing climate. Plant Cell Environ 28:965-981.

Kohno Y, Matsumura H, Ishii T, Izuta T (2005) Establishing critical levels of air pollutants for protecting East Asian vegetation - A challenge. In: Omasa K, Nouchi I, De Kok LJ (eds) Plant responses to air pollution and global change. Springer-Verlag, Tokyo, pp 243-250 
Landolt W, Bühlmann U, Bleuler P, Bucher JB (2000) Ozone exposure-response relationships for biomass and root/shoot ratio of beech (Fagus sylvatica), ash (Fraxinus excelsior), Norway spruce (Picea abies) and Scots pine (Pinus sylvestris). Environ Pollut 109:473-478

Matsuda K, Fukuzaki N, Maeda M (2001) A case study on estimation of dry deposition of sulfer and nitrogen compounds by inferential method. Water Air Soil Pollut 130:553-558

Matsumura H (2001) Impacts of ambient ozone and/or acid mist on the growth of the 14 tree species: an open-top chamber study conducted in Japan. Water Air Soil Pollut 130:959-964

Matyssek R, Günthardt-Goerg MS, Saurer M, Keller, T (1992) Seasonal growth, $\delta^{13} \mathrm{C}$ in leaves and stem, and phloem structure of birch (Betula pendula) under low ozone concentrations. Trees 6:69-76

Matyssek R, Sandermann H (2003) Impact of ozone on trees: an ecophysiological perspective. In: Esser K, Lüttge U, Beyschlag W, Hellwig F (eds) Progress in Botany 64. Springer-Verlage, Berlin Heidelberg, pp349-404

Matyssek R, Bytnerowicz A, Karlsson P-E, Paoletti E, Sanz M, Schaub M, Wieser G (2007) Promoting the $\mathrm{O}_{3}$ flux concept for European forest trees. Environ Pollut 146:587-604

Maurer S, Matyssek R, Günthardt-Goerg MS, Landolt W, Einig W (1997) Nutrition and the ozone sensitivity of birch (Betula pendula): I. Responses at the leaf level. Trees 12:1-10

Mills, G (2004) Mapping Manual 2004, Chapter III Mapping Critical Levels for Vegetation p 52. Available via DIALOG. http://icpmapping.org/cms /zeigeBereich/11 /manual_english.html Accessed 1 May 2009. 
Ministry of Land, Infrastructure, Transport and Tourism (2008) Water Resources in Japan. Available via DIALOG. http://www.mlit.go.jp/tochimizushigen /mizsei/hakusyo/H20/index.html. Accessed 1 May 2009. In Japanese

Ministry of the Environment (1996) About revision of the method for measuring the air pollutants such as sulfur dioxide in the atmosphere. Transmittal from Ministry Environment. Available via DIALOG. http://www.env.go.jp /hourei/syousai.php?id=01000052. Accessed 1 May 2009.

Ministry of the Environment (ed) (2004) Comprehensive report on acid deposition survey. Ministry of the Environment, Tokyo, p 432. In Japanese

National Astronomical Observatory (ed) (2007) Rika Nenpyo (Chronological Scientific Tables 2008). Maruzen, Tokyo, p 1034. In Japanese

Network Center for EANET (ed) (2007) Data report 2006. Network Center for EANET. Available via DIALOG. http://www.eanet.cc/product.html Accessed 1 May 2009

Ohara T, Sakata T (2003) Long-term variation of photochemical oxidants over Japan. J Jpn Soc Atmos Environ 38:47-54. In Japanese with English summary

Ohara T, Akimoto H, Kurokawa J, Horii N, Yamaji K, Yan X, Hatasaka T (2007) An Asian emission inventory of anthropogenic emission sources for the period 1980-2020. Atmos Chem Phys 7:4419-4444

Oksanen E (2003) Physiological responses of birch (Betula pendula) to ozone: a comparison between open-soil-grown trees exposed for six growing seasons and potted seedlings exposed for one season. Tree physiol 23:603-614 
Prather M, Ehhalt D, Dentener F, Derwent R, Dlugokencky E, Holland E, Isaksen I, Katima J, Kirchhoff V, Matson P, Midgley P, Wang M (2001) Atmospheric Chemistry and greenhouse gases. In: Houghton JT, Ding Y, Griggs DJ, Noguer M, van der Linden PJ, Dai X, Maskell K, Johnson CA (eds) The scientific basis. Climate Change 2001: The Scientific Basis. Cambridge University Press, Cambridge, UK and New York pp 239-287

Reich PB (1987) Quantifying plant response to ozone: a unifying theory. Tree Physiol 3:63-91

Simpson D, Ashmore MR, Emberson L, Tuovinen J-P (2007) A comparison of two different approaches for mapping potential ozone damage to vegetation. A model study. Environ Pollut 146:715-725

Sitch S, Cox PM, Collings WJ, Huntingford C (2007) Indirect radiative forcing of climate change through ozone effects on the land-carbon sink. Nature 448:791-795

Stevenson DS, Dentener FJ, Schultz MG, Ellingsen K, Van Noije TPC, Wild O, Zeng G, Amann M, Atherton CS, Bell N, Bergmann DJ, Bey I, Butler T, Cofala J, Collins WJ, Derwent RG, Doherty RM, Drevet J, Eskes HJ, Fiore AM, Gauss M, Hauglustaine DA, Horowitz LW, Isaksen ISA, Krol MC, Lamarque J-F, Lawrence MG, Montanaro V, Müller J-F, Pitari G, Prather MJ, Pyle JA, Rast S, Rodriguez JM, Sanderson MG, Savage NH, Shindell DT, Strahan SE, Sudo K, Szopa S (2006) Multimodel ensemble simulations of present-day and near-future tropospheric ozone. J Geophys Res 111:D08301 
Takeda M, Aihara K (2007) Effects of ambient ozone concentrations on Beech (Fagus crenanta) seedlings in the Tanzawa Mountains, Kanagawa Prefecture, Japan. J Jpn Soc Atmos Environ 42: 107-117. In Japanese with English summary

Tanimoto H, Sawa Y, Matsueda H, Uno I, Ohara T, Yamaji K, Kurokawa J, Yonemura S. (2005) Significant latitudinal gradient in the surface ozone spring maximum over East Asia. Geophys Res Lett 32:L21805

Wakamatsu S, Uno I, Ohara T (1998) Springtime photochemical air pollution in Osaka: Field observation. J Appl Meteorol 37: 1100-1106

Wallin G, Skärby L, Selldén G (1990) Long-term exposure of Norway spruce, Picea abies (L.) Karst., to ozone in open-top chambers : I. Effects on the capacity of net photosynthesis, dark respiration and leaf conductance of shoots of different ages. New phytol 115:335-344

Watanabe M, Yamaguchi M, Iwasaki M, Matsuo N, Naba J, Tabe C, Matsumura H, Kohno Y, Izuta T (2006) Effects of ozone and/or nitrogen load on the growth of Larix kaempferi, Pinus densiflora and Cryptomeria japonica seedlings. J Jpn Soc Atmos Environ 41:320-334.

Watanabe M, Yamaguchi M, Tabe C, Iwasaki M, Yamashita R, Funada R, Fukami M, Matsumura H, Kohno Y, Izuta T (2007) Influences of nitrogen load on the growth and photosynthetic responses of Quercus serrata seedlings to $\mathrm{O}_{3}$. Trees 21:421-432

Witting VE, Ainsworth EA, Naidu SL, Karnosky EF, Long SP (2009) Quantifying the impact of current and future tropospheric ozone on tree biomass, growth, physiology and biochemistry: a quantitative meta-analysis. Glob Chang Biol 15:396-424 
Yamaji K, Ohara T, Uno I, Tanimoto H, Kurokawa J, Akimoto H (2006) Analysis of the seasonal variation of ozone in the boundary layer in East Asia using the Community Multi-scale Air Quality model: What controls surface ozone levels over Japan? Atmos Environ 40:1856-1868

Yoshikado H (2004) One possible factor causing recent trend of photochemical oxidants. J Jpn Soc Atmos Environ 39: 188-199. In Japanese with English summary 
Table 1 The slope and coefficient of determination $\left(R^{2}\right)$ values for the linear regression between AOTX $\left(\mu \mathrm{mol} \mathrm{mol}{ }^{-1} \mathrm{~h}\right)$ and the relative reduction in the annual carbon absorption per one growing season (\%) of Cryptomeria japonica, Pinus densiflora and Larix kaempferi seedlings.

\begin{tabular}{llcccccc}
\hline & & AOT0 & AOT20 & AOT40 & AOT60 & AOT80 & AOT100 \\
\hline Slope & C. japonica & -0.096 & -0.116 & -0.152 & -0.209 & -0.301 & -0.462 \\
& P. densiflora & -0.147 & -0.184 & -0.249 & -0.355 & -0.526 & -0.826 \\
& L. kaempferi & -0.158 & -0.200 & -0.271 & -0.387 & -0.568 & -0.879 \\
& & & & & & & \\
$R^{2}$ & C. japonica & 0.895 & $0.944^{*}$ & $0.983^{* *}$ & $0.988^{* *}$ & $0.949^{*}$ & 0.887 \\
& P. densiflora & 0.736 & 0.813 & 0.899 & $0.959^{*}$ & $0.968^{*}$ & $0.936^{*}$ \\
& L. kaempferi & 0.657 & 0.735 & 0.818 & 0.871 & 0.857 & 0.789 \\
\hline
\end{tabular}

The intercept of each the regression line was adjusted to $100 \%$ (see Materials and Method). Single regression analysis: $* p<0.05 ; * * p<0.01$. 
Table 2 Effects of $\mathrm{O}_{3}$ on carbon concentrations (\%) of plant organs of Cryptomeria japonica, Pinus densiflora and Larix kaempferi seedlings at the end of the second growing season.

\begin{tabular}{llccc}
\hline & & Needle & Stem & Root \\
\hline C. japonica & $\mathrm{CF}$ & $50.5(0.1)$ & $48.5(0.1)$ & $48.4(0.4)$ \\
& $\mathrm{O}_{3} \times 1.0$ & $50.8(0.1)$ & $48.3(0.0)$ & $48.6(0.1)$ \\
& $\mathrm{O}_{3} \times 1.5$ & $50.8(0.2)$ & $48.3(0.1)$ & $48.5(0.3)$ \\
& $\mathrm{O}_{3} \times 2.0$ & $51.0(0.1)$ & $48.5(0.2)$ & $48.6(0.3)$ \\
& $\mathrm{ANOVA}$ & $*$ & n.s. & n.s. \\
& & & & \\
P. densiflora & $\mathrm{CF}$ & $52.8(0.3)$ & $49.6(0.2)$ & $47.8(0.1)$ \\
& $\mathrm{O}_{3} \times 1.0$ & $52.8(0.0)$ & $49.7(0.1)$ & $46.4(0.9)$ \\
& $\mathrm{O}_{3} \times 1.5$ & $52.7(0.1)$ & $49.6(0.1)$ & $46.1(1.0)$ \\
& $\mathrm{O}_{3} \times 2.0$ & $52.4(0.1)$ & $49.5(0.1)$ & $46.5(0.5)$ \\
& $\mathrm{ANOVA}$ & n.s. & n.s. & n.s. \\
& & & & \\
L. kaempferi & $\mathrm{CF}$ & $49.5(0.6)$ & $50.3(0.0)$ & $49.2(0.5)$ \\
& $\mathrm{O}_{3} \times 1.0$ & $49.9(0.4)$ & $50.4(0.4)$ & $48.4(0.1)$ \\
& $\mathrm{O}_{3} \times 1.5$ & $49.1(0.0)$ & $50.7(0.1)$ & $48.4(0.2)$ \\
& $\mathrm{O}_{3} \times 2.0$ & $50.1(0.6)$ & $50.5(0.0)$ & $48.6(0.5)$ \\
& $\mathrm{ANOVA}$ & n.s. & n.s. & n.s. \\
\hline
\end{tabular}

Each value is the mean of 3 replicates, and the standard deviation is shown in parentheses.

The seedlings were exposed to charcoal-filtered air (CF) or three levels of $\mathrm{O}_{3}$ at 1.0, 1.5 and 2.0 times ambient concentration.

ANOVA: ${ }^{*} p<0.05$; n.s. not significant. 
Table 3 The estimated $\mathrm{O}_{3}$-induced reduction in the annual carbon absorption $\left(\mathrm{C}_{\mathrm{red}}, \mathrm{Gg}\right.$ carbon year $^{-1}$ ) of Cryptomeria japonica, Pinus densiflora and Larix kaempferi. Values in the parentheses show the reduction rate (\%) compared to the annual $\mathrm{c}$ arbon absorption at zero AOT60.

\begin{tabular}{|c|c|c|c|c|c|}
\hline Region & Prefecture & C. japonica & P. densiflora & L. kaempferi & Total \\
\hline Hokkaido & Hokkaido & $0.12 \quad(0.23)$ & & $0.49(0.19)$ & $0.61 \quad(0.19)$ \\
\hline \multirow[t]{6}{*}{ Tohoku } & Aomori & $1.18(0.42)$ & $0.26(0.70)$ & $0.21 \quad(0.82)$ & $1.64(0.48)$ \\
\hline & Iwate & $1.76(0.38)$ & $1.54(0.63)$ & $0.77 \quad(0.70)$ & $4.07 \quad(0.50)$ \\
\hline & Miyagi & $0.71 \quad(0.32)$ & $0.25(0.54)$ & $0.04 \quad(0.67)$ & $1.01 \quad(0.36)$ \\
\hline & Akita & $3.80(0.55)$ & $0.21 \quad(1.00)$ & $0.15 \quad(0.90)$ & $4.15 \quad(0.57)$ \\
\hline & Yamagata & $1.44(0.52)$ & $0.13(0.90)$ & $0.22 \quad(0.83)$ & $1.78(0.57)$ \\
\hline & Fukushima & $2.07 \quad(0.49)$ & $1.06(0.79)$ & 0.35 (1.29) & $3.48(0.60)$ \\
\hline \multirow[t]{7}{*}{ Kanto } & Ibaraki & $0.54 \quad(0.72)$ & 0.34 (1.61) & & 0.97 (1.01) \\
\hline & Tochigi & 1.62 (1.19) & 0.25 (1.98) & $0.31 \quad(2.23)$ & 2.18 (1.34) \\
\hline & Gunma & $4.26(1.86)$ & $1.25(3.06)$ & $2.02(3.12)$ & $7.53(2.25)$ \\
\hline & Saitama & 1.33 (2.09) & $0.01 \quad(3.64)$ & 0.15 (3.29) & 1.49 (2.18) \\
\hline & Chiba & $1.01 \quad(1.25)$ & 0.03 (1.97) & & 1.04 (1.27) \\
\hline & Tokyo & $0.57 \quad(1.72)$ & $0.02 \quad(3.35)$ & $0.02 \quad(3.39)$ & $0.61 \quad(1.78)$ \\
\hline & Kanagawa & $0.28 \quad(0.93)$ & $0.02 \quad(1.40)$ & & $0.30(0.94)$ \\
\hline \multirow[t]{9}{*}{ Chubu } & Niigata & $1.53(0.52)$ & $0.08 \quad(0.72)$ & 0.12 (1.95) & $1.73(0.55)$ \\
\hline & Toyama & 1.14 (1.02) & 0.01 (1.79) & 0.02 & 1.17 (1.03) \\
\hline & Ishikawa & $1.57(0.95)$ & 0.29 (1.84) & & $1.86(1.03)$ \\
\hline & Fukui & $1.17(0.59)$ & $0.11 \quad(1.20)$ & & $1.28(0.62)$ \\
\hline & Yamanashi & 0.49 (1.18) & 1.03 (1.88) & 1.82 (2.19) & 3.35 (1.86) \\
\hline & Nagano & 1.09 (1.02) & 1.17 (1.73) & 5.80 (1.98) & 8.05 (1.72) \\
\hline & Gifu & $1.67(0.86)$ & 0.07 (1.38) & 0.58 (1.71) & 2.32 (0.99) \\
\hline & Sizuoka & $1.53(1.06)$ & 0.22 (1.88) & 0.10 & $1.84(1.15)$ \\
\hline & Aichi & $2.05(1.05)$ & $0.10(1.48)$ & & 2.15 (1.06) \\
\hline \multirow[t]{7}{*}{ Kinki } & Mie & $1.24(0.94)$ & 0.16 (1.59) & & $1.40(0.98)$ \\
\hline & Shiga & $0.59 \quad(0.95)$ & $0.03(1.55)$ & & $0.62(0.97)$ \\
\hline & Kyoto & $0.83 \quad(0.88)$ & 0.17 (1.41) & & $1.00(0.94)$ \\
\hline & Osaka & $0.07 \quad(1.39)$ & 0.06 (1.93) & & 0.14 (1.60) \\
\hline & Hyogo & $2.00(0.79)$ & 0.37 (1.51) & & $2.38(0.85)$ \\
\hline & Nara & 1.92 (1.19) & 0.03 (1.95) & & $1.95(1.20)$ \\
\hline & Wakayama & 1.47 (1.02) & 0.13 (1.98) & & $1.60(1.06)$ \\
\hline \multirow[t]{5}{*}{ Chugoku } & Tottori & $1.03(0.79)$ & $0.62(1.31)$ & & $1.65(0.93)$ \\
\hline & Shimane & $1.92(1.20)$ & 1.78 (2.07) & & $3.70(1.51)$ \\
\hline & Okayama & $0.54 \quad(0.75)$ & 0.35 (1.28) & $0.02 \quad(1.27)$ & $0.91 \quad(0.90)$ \\
\hline & Hiroshima & 0.69 (1.27) & $0.41 \quad(2.26)$ & & $1.10(1.51)$ \\
\hline & Yamaguchi & $0.96(0.85)$ & 0.39 (1.36) & & $1.35(0.96)$ \\
\hline \multirow[t]{4}{*}{ Shikoku } & Tokushima & $2.37 \quad(0.99)$ & 0.15 (1.38) & & $2.52(1.01)$ \\
\hline & Kagawa & $0.01 \quad(0.61)$ & $0.09(0.90)$ & & $0.11 \quad(0.85)$ \\
\hline & Ehime & $1.67(0.77)$ & 0.12 (1.26) & & $1.79(0.79)$ \\
\hline & Kochi & 2.45 (0.69) & 0.10 (1.09) & & $2.54(0.70)$ \\
\hline \multirow[t]{7}{*}{ Kyusgu } & Fukuoka & $1.00(0.67)$ & $0.02(0.79)$ & & $1.03(0.67)$ \\
\hline & Saga & $0.67 \quad(0.62)$ & $0.01 \quad(0.97)$ & & $0.68(0.62)$ \\
\hline & Nagasaki & $0.40 \quad(0.63)$ & $0.01 \quad(0.91)$ & & $0.42(0.64)$ \\
\hline & Kumamoto & $1.76(0.43)$ & $0.08 \quad(0.75)$ & & $1.84(0.44)$ \\
\hline & Oita & $2.12(0.50)$ & $0.04(0.76)$ & & $2.17(0.50)$ \\
\hline & Miyazaki & $3.62(0.67)$ & 0.12 (1.16) & & $3.73(0.68)$ \\
\hline & Kagoshima & $1.66(0.51)$ & $0.09(0.86)$ & & $1.75(0.52)$ \\
\hline Total & & $63.91(0.73)$ & $13.82(1.23)$ & $13.27(1.35)$ & $91.00(0.84)$ \\
\hline
\end{tabular}




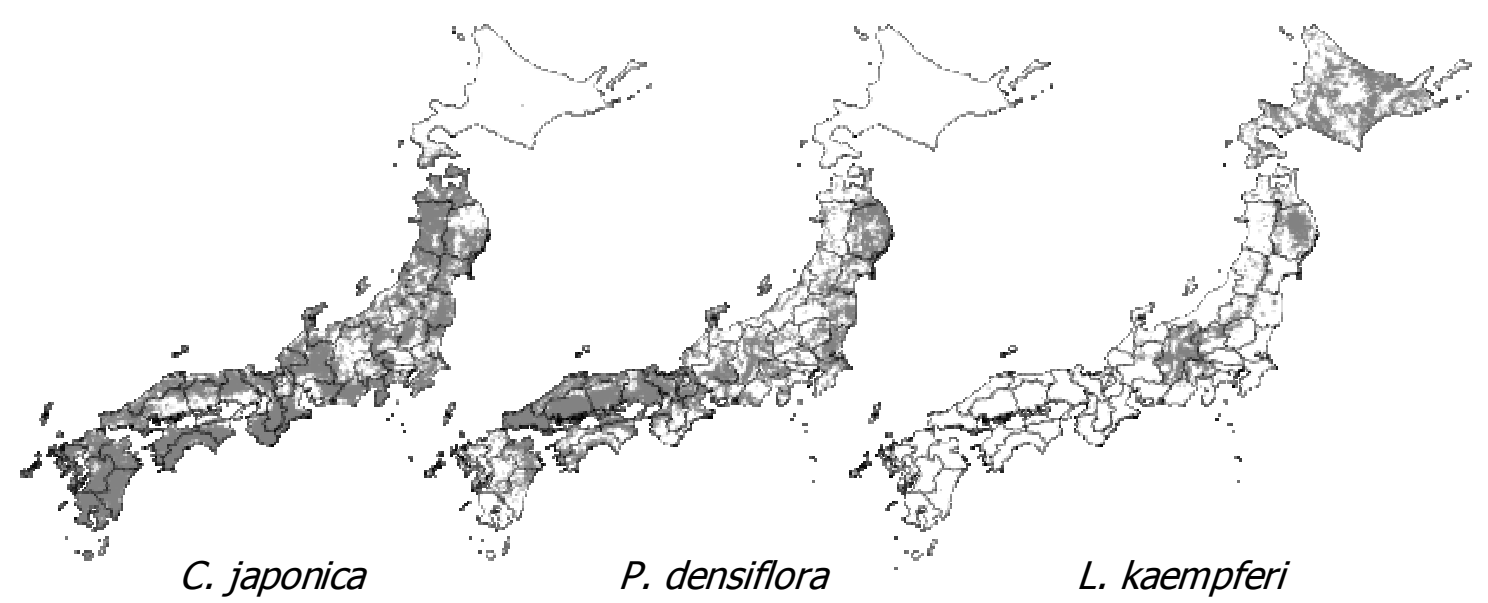

Fig. 1 The habitats of Cryptomeria japonica, Pinus densiflora and Larix kaempferi in Japan 


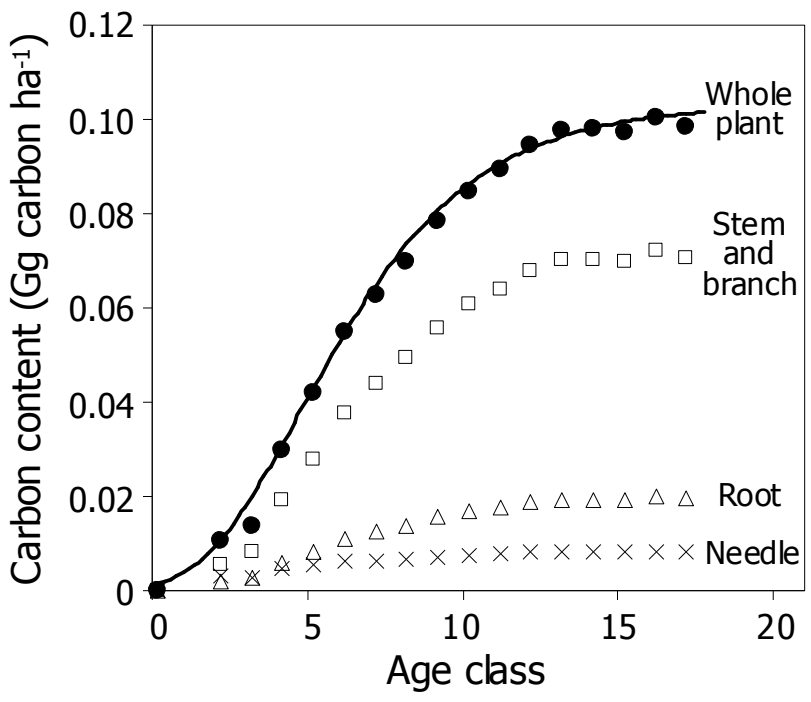

Fig. 2 Example of the relationship between forest age class (Class $1=1-5$ years, Class $2=6-10$ years etc.) and carbon content of trees per area (Cryptomeria japonica in Tokyo Prefecture) 


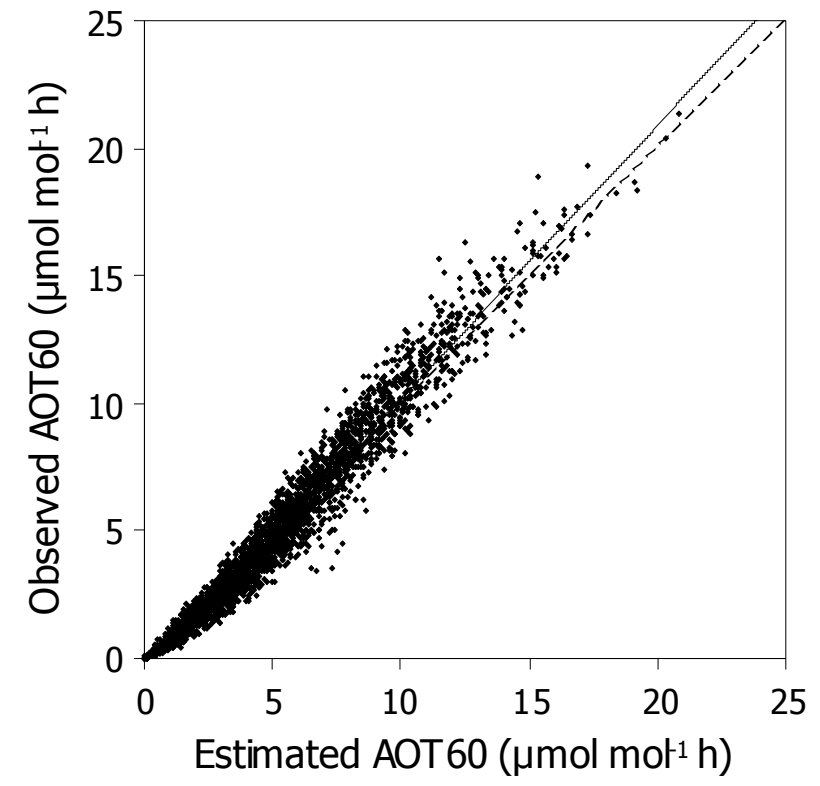

Fig. 3 Comparison between estimated and observed AOT60. The solid and dashed lines indicate the regression line $\left(\mathrm{y}=1.071 \mathrm{x}-0.526, R^{2}=0.964\right)$ and $1: 1$ line, respectively 


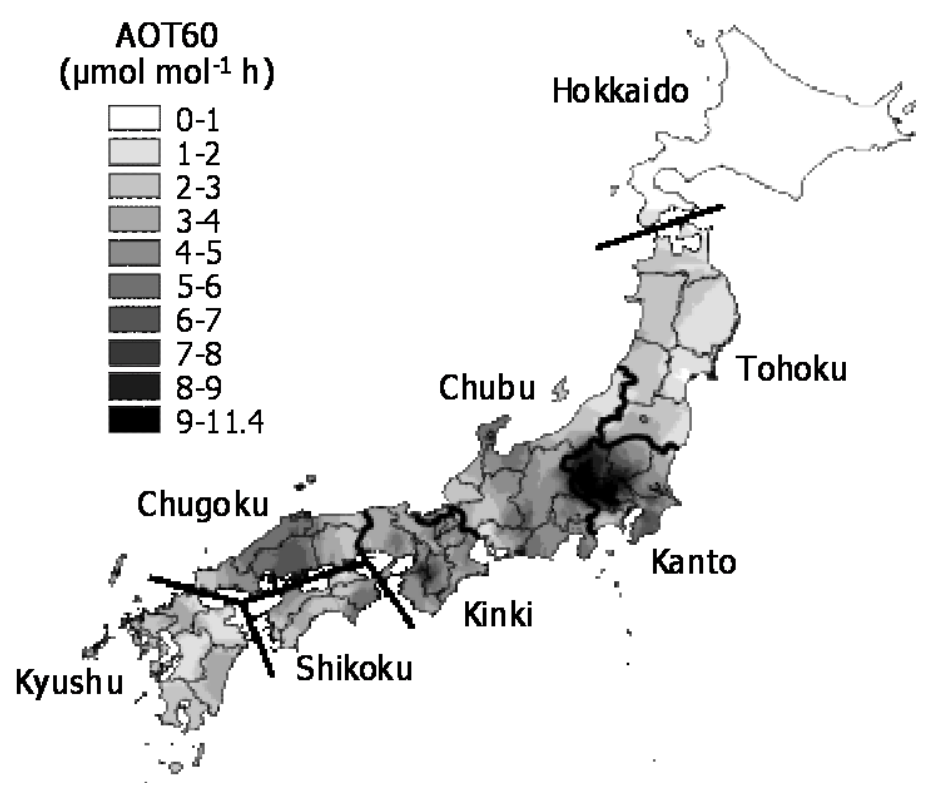

Fig. 4 The estimated AOT60 in Japan. The AOT60 data was accumulated during 0600-1800 hours from April to September and averaged from 2000 to 2004 


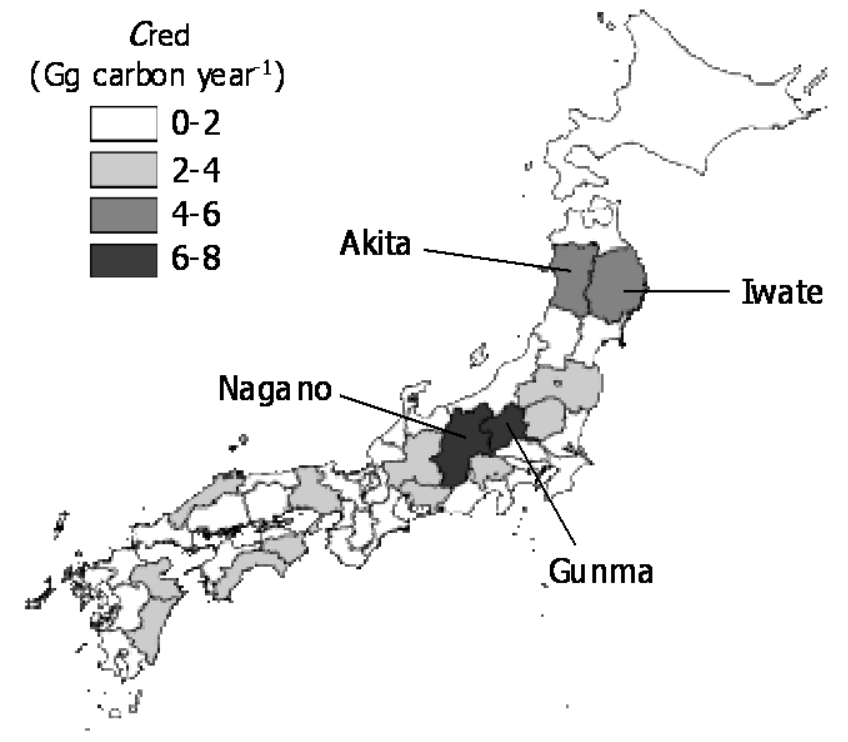

Fig. 5 The estimated $\mathrm{O}_{3}$-induced reduction in the annual carbon absorption $\left(C_{\mathrm{red}}\right)$ in Japan. The values were the sum of the $C_{\text {red }}$ of Cryptomeria japonica, Pinus densiflora and Larix kaempferi 


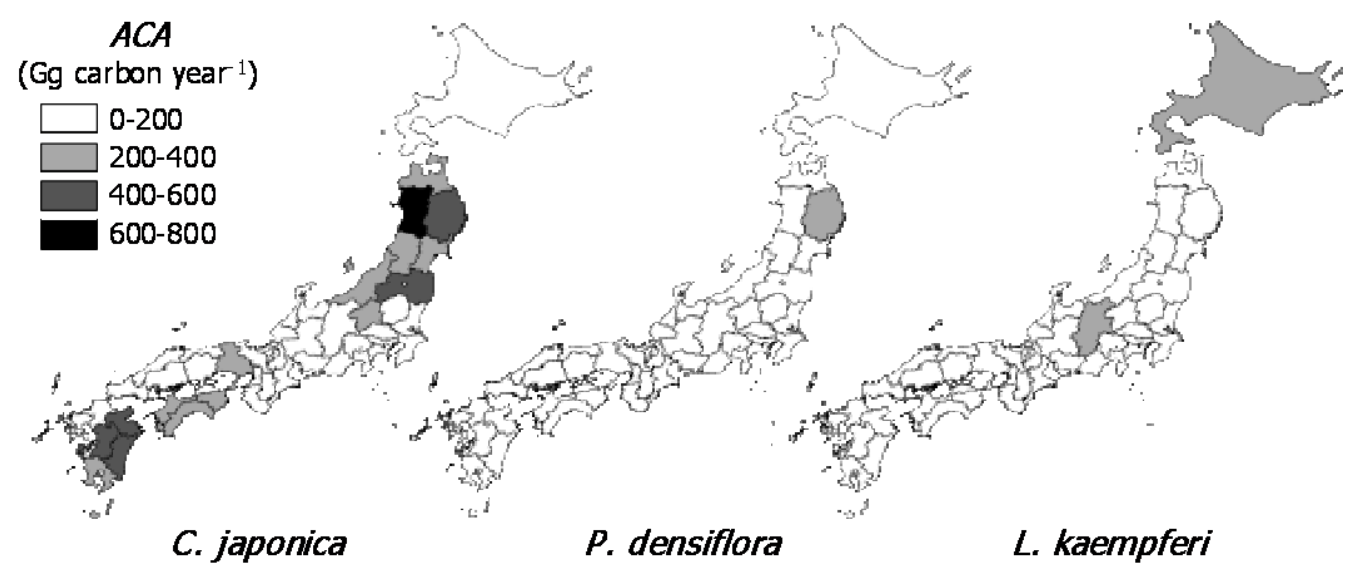

Fig. 6 The annual carbon absorptions (ACA) of Cryptomeria japonica, Pinus densiflora and Larix kaempferi in Japan 